\title{
An Analysis of the Impact of the Use of Gadget on Children's Language and Social Development
}

\author{
Dewi Nilam Sari
}

Early Childhood Department, Padang State University, Padang, Indonesia, dewinilamsari1985@gmail.com

\begin{abstract}
As the development of technologically very rapidly with the development of a variety of functions and features, making gadgets are not only used by adults, but also by younger children. With many interesting features that they can use to make children an early age to be one of consumer gadgets. The gadget is seen to have a negative impact on the development of children, the gadget can inhibit the language and social developments. When children take advantage of the gadgets that they have to play games, watch videos and so will take time for the children to play and socialize with their peers and also prevents children in developing language, but on the other hand gadget could also provide a positive appears on the child's development. With so many interesting features on offer and often make children familiar with it quickly. Many of the impacts and benefits of the gadgets among others, to facilitate a child in a child's creativity and intelligence. As the application of coloring, learning to read and write letters certainly a positive impact on brain development of children. Children do not require much time and effort to learn to read and write in a book or paper. Children also will be more eager to learn because such applications are usually complemented by interesting pictures. and writing letters is certainly a positive impact on brain development of children.
\end{abstract}

Keywords: Gadget, Children's language children's development

\section{INTRODUCTION}

Along with the times, technology development is also experiencing rapid growth. Various types of emerging technologies and new features are always from day to day. The needs on technology is one important requirement at this time. This is because the technology is needed for various purposes. One technology that is indispensable to human life is a gadget. In the gadget, there are various features that can be utilized by humans in a variety of ways, one of the main features of the smartphone is the internet. Internet invention changed the world becomes more dynamic and fast paced. Internet advancement has touched many facets of human life.

A few years ago the gadget is only used by the businessmen of the middle down. The reason they use the gadgets is to facilitate their business. But today, gadgets are not only used by businessmen alone, but must-have for everyone from adults, teenagers and even children who should not have been feasible to use it, this is caused gadget has a variety of features and applications that are interesting, varied, interactive, flexible so that adds to the appeal. (Mayenti \& Sunita, 2018)

At present, the gadget cannot only be harnessed and used by adults, but also by younger children. We can see in public places virtually all young children holding the gadget. With so many interesting features on offer and often make children familiar with it quickly. Many of the impacts and benefits of the gadgets among others, to facilitate a child in a child's creativity and intelligence. As the application of coloring, learning to read and write letters certainly a positive impact on brain development of children. Children do not require much time and effort to learn to read and write in a book or paper. Children also will be more eager to learn because such applications are usually complemented by interesting pictures. Other than that, the ability to imagine children as well honed. This is in line with the views expressed by psychologists Hadiwidjodjo (2014, in AlAyouby, 2017), namely:

Simplify Communication. Gadget is one tool which has advanced technology. So everyone can easily communicate. Building a child's creativity (Gadget provides a variety of information that can also encourage children to be more creative). Children will be easier to find all the necessary information and news to him, especially in terms of learning while playing, or playing while learning. In this age, the child was still in the future exciting to play. But not escape from a learning process that must be done.

One interesting feature that is very popular with children is the Internet, with the Internet they can access their favorite video, play online games and so on. Of the various applications on the gadget and can be accessed through the internet, youtube be number one among early childhood. From youtube they could watch cartoons or animations on their favorite, in addition to video cartoon 
and animation, there are also many videos instructive that can be accessed by children, such as video learn to recognize numbers and letters, recognize colors, shapes, until a video featuring health in the form of animation. As parents are smart, we should be able to assist children and choose which things to leave a positive impact and negative for children.

\section{DISCUSSION}

Early childhood has unique characteristics because they are at a very rapid growth process and fundamental to the next life. In psychology early childhood have different characteristics and with children over the age of 8 years (children end).

According to Suryana (2013) characteristic of early childhood are:

a. Egocentric child is to see the world from the standpoint of curiosity and his own interests.

b. The child has a high curiosity, the daughter of the view that the world is filled with things that are interesting and amazing.

c. Child is unique that is has its own uniqueness as learning styles, interests and family background.

d. Son of a rich imagination and fantasy that children are interested in things that is imaginative so they are rich in fantasy.

e. Kids have a short concentration power that children are always quickly turned his attention to other activities, unless the activity is indeed an interesting and varied activities.

With the characteristics of such children, make children curious and try new things. For early childhood, or so-called "age kid now" gadgets is that they use. Various features offered by the gadget make the children spend a lot of time in play. The gadget has a positive impact how related to the characteristics and early childhood development. Based on research conducted by (Kiftiyah, Sagita, and Asr) comparison subjects research results explain that the children of the three subjects showed a growth area in the cognitive areas of imagination, language, curiosity and concentration. The most prominent and rapidly growing in the stimulation of YouTube videos for the three children are in terms of language and imagination. This is certainly not independent of the age of the child who was present in the environment mimic stage, so that stimulation of the video-based English language, songs and prayers can be recorded well in their memory. Besides the subject between one and two show trends of development in the introduction of color.

In line with the findings Kurniawati (2013) in Kiftiyah (stimulation audio-visual of the video is able to deliver optimized development of knowledge the colors are more effective in early childhood. While the findings in the area of the child's imagination, the interesting thing is the way children interpret their environment in accordance imagination of what contained in a given video content. The concept is the same as the development of egocentrism in children characterized by perceiving the outside world at will. Active behave children here can be said to constitute a potential kinesthetic intelligence that will develop in the child.

But like a blade, the gadget is not only a positive impact on the child, but also has a negative effect. Psychological terms, childhood is a golden age where children learn to know what is not yet known. If childhood is already addicted and negatively affected by the gadget, then the childrens development will be hampered, due to childhood experiences have a powerful influence on subsequent developments. Moreover, unwitting children often apply the "What You See is what you Get". This implementation has the meaning of what is seen by children is a lesson, what if no focused and integrated guidance of parents and families, child development will lead to the negative side. At an early age is the stage of development of motor intelligence, the intelligence of thinking, emotional intelligence, language and communication shows that early childhood is the future of a nation's assets that must be considered in each phase of development. (Mayenti \& Sunita, 2018).

There was also an effect on language development in children. when children watch a video on YouTube or other sites, making the child only one-way communication, where it has a serious impact on early childhood. We can see that a lot of animated films that only displays the image without any dialogue in the story, which makes communications child in one direction, in addition to mute the video as well makes children lose time to get to know and learn new vocabulary. In addition, we see examples of this bus children aged 2 years has been introduced with the gadget, it will reduce the quality of children's two-way communication. So that children experience difficulties when communicating with others or in other words, the child will experience speech delay. Whereas the development of children's language skills is an ability that is very important to communicate, especially for those who have entered into the preschool education environment, especially kindergarten. In this regard, Learning early goal (1999) in Susanto (2011) argued that the purpose of the development of language at an early age is described as follows: (a) Enjoys listening, listening, using spoken language and more prepared for play and learning. (B) Investigate and try to sounds, words and text (c) Listening with pleasure and responding to stories, flow and rhythms, and rhymes and fix their own stories, stories, songs, music and rhyme and rhythm, (D) Use language to create, describe the role and experience (e) Using talks to organize, sort, clear thinking, ideas, feelings and events. (F) Support, listening attentively (g) Respond to they hear the comments, questions and the relevant actions. (H) Interaction with other mortal, negotiate planning and activities and wait for the turn in conversation. (I) Expand their vocabulary, examines the meaning and sound of new words (j) Telling the stories in the correct order on the story illustrates a pattern language.

Generally the stages of child development can be divided into several age ranges, each of which shows the characteristics of its own. According to Guntur (1998) 
(Susanto, 2011, p. 75), the stages of this development as follows:

- Phase 1 (prelinguistic), which is $0-1$ years. This phase consists of:

1. Phase palpate-1 (first prelinguistic). This stage starts from the first month until the sixth month in which the child will start crying, laughing, and screaming.

2. Phase palpate-2 (paralinguistic second). This stage there is essentially a word without meaning stages ranging from 6 months to 1 year.

- $\quad$ Phase 2 (linguistic). This stage consists of stages I and II, namely:

1. Phase-I; holophrastic (1 year old), when children begin to express the meaning of the whole phrase or sentence in one word. This stage is also characterized by the vocabulary of children up to approximately 50 vocabularies.

2. Phase-2; phrase (1-2 years), at this stage the child is able to utter two words (speech two words). This stage is also characterized by the vocabulary of children up to 50-100 vocabulary

- $\quad$ Phase 3 (development of grammar, i.e. preschool 3, 4, 5 years old). At this stage the child is able to create a sentence, like a telegram. An examination of the development of grammar such as: SPO, children can extend words into one sentence.

- $\quad$ Stage 4 (grammar before adulthood, i.e. 6-8 years). This stage is characterized by the ability that is able to combine simple sentences and complex sentences.

Bruner Susanto (2011), states that children learn from concrete to abstract through three stages, namely enactive, iconic and symbolic.

- In the enactive stage. Kids interact with objects in the form of objects, people and events. Of this interaction, children learn the names and recording characteristics of objects and events. That is why children aged 2-3 years old children will be a lot to ask "what" "what's that" etc.

- At that stage the child begins to learn to develop the iconic symbols of the object.

- Symbolic process occurs when children develop the concept. By the same process, children learn about various objects such as glasses, drink and water

According to research conducted by the Son and Patmaningrum (2018) TK students in Bandung routine use gadgets, making children miss time with their families to share their daily routine, because when both (children and mothers) have started to play the gadget, each having his own world. Moreover, because the lack of social interaction to make children become individual figure who does not care about the circumstances. Gadget make children more easily gain access to information and technology media, so that children become lazy moving and active. They prefer to sit and enjoy the world in the gadget itself. Things like this will certainly affect the child's development, both in terms of physical, motor, psychological and social development. They become no longer interested in playing with their peers because it is more interested in digital games. In addition children will be more difficult to concentrate on the real world because they are already familiar with the digital world (Ameliola \& Nugraha, 2013).

Based on research conducted by Sapardi (2018) mentions that found based on the results of research conducted in children whose development deviates from gadgets using seen most children are not normally in use gadgets (over 30 minutes per week). The use of gadgets too long to make children lazy to move and doing activities, less interact with the environment, and hamper the process of socialization of children, so it can affect a child's development.

While to become individuals capable of society needed three socialization process. This socialization process seems separate, but actually relate to each other, as suggested by (Hurlock, 1996) is as follows. (1) Learn to behave in a socially acceptable manner. (2) Learning to play a social role in the community. (3) Developing attitudes / social behavior to other individuals and social activity in the community.

In its development, based on the three stages of this social process, the individual will be divided into two groups, namely the social and individual non-social individuals. Social individual groups are those whose conduct a third reflects the socialization process.

They were able to follow the desired group and accepted as a member of the group. Sometimes they always want the other person and feel lonely if they are alone. In addition they also feel satisfied and happy if always be with others. The group of non-social individuals, they are people who are not successful third reflect socialization processes. They are individuals who do not know what to expect social groups so that their behavior does not correspond to social expectations. Sometimes they grow into antisocial individuals, i.e. individuals who know the expectations of social groups, but deliberately against it. As a result of this antisocial individual is rejected or ostracized by social groups.

Besides the two groups above, in this social development unisex terms Introvert and extrovert individuals. Introvert is a person's tendency to withdraw from social environment. Interests, attitudes or decisions taken are always based on feelings, thoughts, and his own experiences. People with a tendency introvert, usually quiet and do not need other people because they feel all their needs can be met alone.

Extrovert is a person's tendency to direct attention to the outside of him so that all the interests, attitudes, and decisions are taken more determined by events that occur outside of him. People usually tend to be active extrovert, gregarious and welcoming.

An expert expressed introvert and extrovert just a type of reaction that indicated a person. If someone shows a continuous reaction as it is or has become a habit then be 
regarded as a type of personality. While other experts suggest that a healthy or balanced personality must have both of these tendencies. Thus, the need to deal with the social environment and the need for achievement and selfreflection can both be satisfied.

Good or bad impact on children of gadgets depending on how parents restrict and filter out which ones are good and which are bad for their children.

\section{CONCLUSION}

Eyes like two sides of the blade, the gadget can provide positive and negative effects as well. As teachers and parents, we must be smart to address the use of gadgets on children, how we are able to utilize gadgets to a more positive and minimize the negative impact caused by the gadget in order to achieve optimal development in children.

With so many interesting features on offer and often make children familiar with it quickly. Many of the impacts and benefits of the gadgets among others, to facilitate a child in a child's creativity and intelligence. As the application of coloring, learning to read and write letters certainly a positive impact on brain development of children. Children do not require much time and effort to learn to read and write in a book or paper. Children also will be more eager to learn because such applications are usually complemented by interesting pictures. In addition, the ability to imagine children as well honed.

The gadget also obtains any negative impact child development. Psychological terms, childhood is a golden age where children learn to know what is not yet known. If childhood is already addicted and negatively affected by the gadget, then the children's development will be hampered, due to childhood experiences have a powerful influence on subsequent developments.

So, as teachers and parents, we must be smart to address the use of gadgets in children, how we are able to utilize gadgets to a more positive and minimize the negative impact caused by the gadget in order to achieve optimal development in children

\section{REFERENCES}

[1] Al-Ayouby, H. (2017). Dampak Penggunaan Gadget Pada Anak Usia Dini, Studi Di PAUD Dan TK Handayani Bandar Lampung. Universitas Lampung.

[2] Anita, S. (2015). Perkembangan Bahasa Anak Usia Dini. Jurnal Al-Shifa, Vol. 06. No. 02, 172-173.

[3] Hurlock, E. B. (1996). Psikologi Perkembangan. Jakarta: Erlangga.

[4] Kiftiyah, I. N., Sagita, S., \& Ashar, A. B. (N.D.). Peran Media Youtube Sebagai Sarana Optimalisasi Perkembangan Kognitif Pada Anak Usia Dini. Prosiding Semnas Penguatan Individu Di Era Reformasi. Kediri.
[5] Mayar, F. (2013). Perkembangan Sosial Anak Usai Dini Sebagai Bibit Untuk Masa Depan. Jurnal AlTa'lim, Jilid 1.

[6] Mayenti, F., \& Sunita, I. (2018). Dampak Penggunaan Gadget Terhadap Perkembangan. Jurnal Photon, 209.

[7] Putra, Asaas \& Patmaningrum. (2018) Pengaruh youtube di smarthphone terhadap perkembangan komunikasi interpersonal anak. Jurnal penelitian.

[8] Sapardi, V. S. (2018). Hubungan Penggunaan Gadget Dengan Perkembangan Anak Usia. Menara Ilmu, 143.

[9] Seotjiningsih, C. H. (2012). Perkembangan Anak : Sejak Pembuahan Sampai Kanak-Kanak Akhir. Jakarta: Prenada.

[10] Susanto, A. (2011). Perkembangan Anak Usia Dini. Jakarta: Kencana.

[11] Upton, P. (2012). Psikologi Perkembangan. Jakarta: Erlangga. 